\section{Beauty Is Almost Truth}

István D. Rácz:

A szép majdnem igaz: Philip Larkin

költészete [Beauty Is Almost Truth:

The Poetry of Philip Larkin]

Orbis Litterarum Series 7 (Debrecen:

Kossuth Egyetemi Kiadó, 1999)

Poets and Masks: The Quest for Identity in British Poetry after 1945 was a pioneer work of István D. Rácz, both in terms of opening up formerly lesserknown realms of contemporary British poetry for the Hungarian reader and in paving the way for other academic studies in the Orbis Litterarum series. His second book, which is not a sequel to the first one, narrows down its scope to Philip Larkin's poetry and further explores it in fine details.

Defining its aims and methods, Beauty Is Almost Truth identifies the relationship of Larkin the poet to the Larkin oeuvre as a matter of frequent debate, adding that the book intends to answer what the proper nature of this relationship is. Analyses of biographical data and interpretation of literary texts form the bases of the investigation, serving well Rácz's attempt to write a guide to the Larkin canon. The categories he employs ('poet,' 'lyric I' or 'implied author,' 'speaker') may sound famil- iar from his first book, which in turn may explain why the present publication lacks the bulky "Theoretical Questions" section in Poets and Masks.

The book opens with a short biography mentioning Sydney Larkin's dominant father figure and the young Philip's inhibitions as two important factors from the poet's childhood, Larkin's friendship with Kingsley Amis and the two (relatively) short spells in Wellington and Belfast as significant in his adult life. The sketchy account of Larkin's later years in Hull is mostly taken up by the description of his editing The Oxford Book of Twentieth Century English Verse.

The same part continues with listing and analysing three main characteristics of Larkin's personality: his conservatism, his relation to transcendence and the tension arising from the mental constraint to confess and the urge to conceal himself. Rácz sees the "wish to conserve" as everpresent both in Larkin's personality and his poetry, just as his "ambivalent" and "contradictory" relationship to transcendence is apparent in both. Considering the third category, Rácz maintains that it reflects both Larkin's personality and general characteristics of 19 th and 20th century English literature. 
The author does not ignore Larkin's letters and the many heated debates his poems have generated in literary circles. Rácz uses the former to refine the picture of Larkin's personality and, in other chapters, to support his own interpretations of the texts, the latter to present different critical voices of the age (Charles Tomlinson, Stephen Regan, James Booth, Janice Rossen, Andrew Motion).

The second part, "The Beginning of the Career," encompasses the period of maturation from 1940 until the publication of "The Less Deceived," Larkin's first literary success as a poet in 1955. In the next three chapters - "The Construction of the Poetic Identity," "The North Ship (1945)," "Jill (1946) and A Girl in Winter (1947)" - Rácz tries to recreate the mental process which formed Larkin's poetic identity. Reckoning that the poet's early works are not of Larkin's best, Rácz mostly traces the influences rather than analysing and interpreting individual texts in depth.

The first chapter is a biographicalbased analysis of Larkin's first attempts at forming his own (poetic) identity. Having collected an impressive amount of data on Larkin, Rácz manages to draw the intricate system of correspondences between Larkin's early years as a poet and the three books of poetry written later. Especially interesting are the paragraphs on Larkin's inventing the figure of Brunette Coleman, which seems an essential discovery from the point of view of his great dramatic monologues and masks.

While "The Construction of the Poetic Identity" relies heavily on Larkin's correspondence with Kingsley Amis and James Sutton, "The North Ship (1945)" focuses on Larkin's first volume of poetry. The few passages cited here and the observations that follow present much evidence of the early works' being forerunners of certain poems from The Less Deceived, The Whitsun Wed. dings or High Windows ("XVI" vs. "Sad Steps," "Love Again" or "Aubade").

The next chapter with the analysis of Jill and A Girl in Winter is reminiscent of "The Agnostic Lyric I: The Poetry of Philip Larkin" from Poets and Masks, where Rácz had already discussed and identified the main characteristics of mask creation employed fully-fledged in Larkin's poetry.

The second part describing the beginning of Larkin's career comes to an end around page fifty, once again leaving us content with the findings and assured that the author's conclusions are based on a thorough re- 
search. Yet it is also here that some readers will first find fault with the book.

The last three chapters might induce disappointment in those who have read Poets and Masks, which may well be attributed to the many resemblances between Beauty Is Al. most Truth and Rácz's first publication in the Orbis Litterarum series. Some of these "resemblances" include rephrased passages and conclusions already arrived at in the earlier book, but perhaps more disturbing are the copy-paste sections of the "The Construction of the Poetic Identity" and "Jill and A Girl in Winter" (the creation of Brunette Coleman's figure, John Kemp and Jill, excerpts from Larkin's letters, etc). Sadly, the same is true for the following parts as well; the fifty pages of "The Agnostic Lyric I: The Poetry of Philip Larkin" are all included in the present hundred and thirty-page analyses of The Less Deceived, The Whitsun Weddings and High Windows almost word for word.

Even though the aims and methods of Poets and Masks and those of Beauty Is Almost Truth are similar, the "guide book" character of the second would certainly have allowed for a change in the wording and organisation of the (otherwise immense) material.
It is also true, however, that the majority of readers will not compare the two books and readily follow Rácz's compelling and otherwise relevant analyses.

The third part of the book, "The Mature Poet," is by far the bulkiest, concentrating on Larkin's three, significant volumes of poetry. Working himself through the Larkin oeuvre, Rácz discusses individual poems while keeping his original aim in mind, that is, the analysis of the relations within the tripartite system of poet, lyric I and speaker in the poem. Fortunately Rácz's never stops at discussing the relations within Larkin's poetry only, but manages to trace influences back to predecessors as well. Browning, Yeats and Eliot are all comfortable reference points, first of all because of these poets' obvious association with the dramatic monologue and with masks in British poetry.

Comparing The Less Deceived with The North Ship and XX Poems, Rácz characterises the new volume as "not only thought-provoking, but one that is able to reveal something significant about the agnostic lyric I, who is, nonetheless, willing to discover the world." The author discusses most of the volume's twentynine poems and, in the majority of cases, arrives at the conclusion that 
the lyric I stays in the background while experience is pushed into the foreground (as in "Deceptions"). Citing Swarbrick's opinion on "Lines on a Young Lady's Photograph Album" he seems to agree that Larkin though he was a literary heir to both Eliot and Yeats - managed to find a path different from theirs and "construct a voice that is socially identifiable, yet preserves its own anonymity."

There is a poem which Rácz separates from the rest on the basis of its divergence. In "Church Going" the lyric I and the speaker merge into one, which Rácz identifies as a convergence of Larkin's ontological conservatism and his obsession with the conservation of acquired experience. The poem with its final epiphany, he claims, revitalises certain characteristics of romantic poetry.

The parallel with Beckett's Wait. ing for Godot seems a valuable new addition to the analysis, just as the many references to other critics (Parkinson, Watson, Eduard Vlad, Press \& Booths, Tolley, Kennedy).

The poems of The Whitsun Wed. dings are still centred around the same questions with experience and its relation to the lyric $I$ in the focus of attention. What is new in the book is in its foregrounding the problems of time and space, with the latter becoming the main topic in many of the major poems ("Whitsun Weddings," "Here," "The Importance of Elsewhere"). Rácz - once again citing Andrew Swarbrick claims that the "wish to dissolve in otherness" becomes more emphatic in Larkin's second volume of poetry as opposed to The Less Deceived poems' self-analysing approach.

In connection with "Naturally the Foundation with Bear Your Expenses" Rácz echoes Booth, who separated four poems in the Larkin oeuvre on the basis of their containing a distinctly different speaker from the lyric I "Wedding Wind," "Study of Reading Habits," "Livings"). According to the author "the mainstream of The Whitsun Weddings is signalled by the poems in which the other becomes part of the lyric I in one way or another." .

As in the earlier chapter, Rácz again identifies a few poems in the volume as divergent in tone from Larkin's usual texts which reflect his typically agnostic stance. "For Sydney Bechet," "Toads Revisited" and most notably "Whitsun Weddings" exhibit playfulness and jocundity. "Love" is the central problem of The Less Deceived, while those of The Whitsun Weddings are "isolation" and "death. High Windows, Larkin's last volume of poetry, is characterised by 
its "angry voice" - says Swarbrick, a critic Rácz often seems to agree with. In this case he shares Swarbrick's opinion on High Windows claiming that the "cynic, coldly supercilious and sometimes boorish" character is Larkin's favourite in this volume. $\mathrm{He}$ views the frequent use of the "angry voice" as resulting from the changes in the poet's life and in the socio-cultural conditions of the second half of the sixties. "Aubade" and "Love Again," two poems that Larkin did not include in any of the volumes, close the third part of the book with a short conclusion to follow afterwards.

On the whole István D. Rácz has given us another impeccably researched book, one that will surely become a landmark in Larkincriticism among students and teachers alike. According to Rácz's original intentions, the publication successfully balances between the different roles, and may serve as an informative university textbook both for English speakers and others, with the academic standards always kept in mind.

Due to its "guide book" character the publication might perhaps foster an interest in the wider Hungarian public towards contemporary British poetry, and it might also bring with it the need for new translations of the Collected Poems of Philip Larkin as well.

PÉTER PÖLCZMANN 